Vol 2 No 2 Desember 2021

Jurnal AlphaEuclidEdu

Received: 21/12/2020; Resived: 24/08/2021; Accepted: 31/12/2021

\title{
IDENTIFIKASI MISKONSEPSI DALAM MENYELESAIKAN SOAL PERTIDAKSAMAAN LINEAR SATU VARIABEL YANG MEMUAT NILAI MUTLAK
}

\author{
Yulya Kusumawati ${ }^{1}$, Halini $^{2}$, Hamdani ${ }^{3}$ \\ ${ }^{1,2,3}$ Program Studi Pendidikan Matematika, FKIP, Universitas Tanjungpura, Pontianak \\ Email: yulya.kusumawati16@gmail.com
}

\begin{abstract}
This research aims to describe the forms of student misconceptions and the factors that cause misconceptions experienced by students in solving linear inequality problems with one variable containing absolute values in class X SMA Muhammadiyah 1 Pontianak. The subjects of this research were students of class X IPA 3 SMA Muhammadiyah 1 Pontianak, totaling 25 students. The research uses descriptive method as the research method. Case study is a form of research used. The results of the research revealed that the research subjects experienced five forms of misconception, namely notation misconceptions experienced by 1 student or by 4\%, generalizing misconceptions experienced by 3 students or by $12 \%$, misconceptions of the application of rules experienced by 6 students or by 24\%, calculation misconceptions experienced by 2 students or by $8 \%$, and specialization misconceptions experienced by 3 students or $12 \%$. The misconceptions experienced by these students are caused by wrong intuition and incomplete reasoning, where students' intuitive thoughts that arise spontaneously when solving problems are still wrong and students' reasoning or logic is still wrong in drawing conclusions and being too broad in generalizing.
\end{abstract}

Keywords: Misconceptions, Two-Tier Diagnostic Test, One Variable Linear Inequality

\section{Pendahuluan}

Pembelajaran matematika yaitu suatu cara siswa dan juga sumber belajar yang saling berinteraksi untuk mempermudah siswa dalam mempelajari matematika. Pembelajaran matematika sendiri memilikitujuan supaya siswa memiliki kompetensi dalam bidang matematika (Firdaus, 2017). Disisi lain, tujuan dari pembelajaran matematika yaitu supaya siswa dapat mengerti konsep matematika, dapat memanfaatkan cara bernalar yang dimilikinya dalam menyampaikan ide dan pernyataan dari matematika, merepresentasikan suatu ide matematika menggunakan simbol atau yang lainnya untuk menjelaskan suatu permasalahan matematika, dan mampu memecahkan masalah matematika (Depdiknas, 2006).

Pembelajaran matematika terdiri dari konsep-konsep yang berurutan, sehingga dapat diartikan bahwa konsep sederhana pada matematika dipakai untuk memahami konsep yang lebih kompleks pada matematika (Ramadhan dkk, 2017: 145). Pernyataan Ramadhan dkk dapat diartikan bahwa konsep-konsep dalam matematika sangat berkaitan. Jika konsep matematika sebelumnya kurang dikuasai maka kemungkinan akan sulit untuk menguasai konsep berikutnya. Sunardi (dalam Isyam dkk, 2019: 75) menyatakan konsep sebagai ide atau gagasan yang bersifat maya dan dipakai untuk mengklasifikasikan beberapa objek apakah objek tersebut merupakan contoh atau bukan contoh. Konsep matematika harus dipahami dengan benar dan tepat karena konsep tersebut akan dipakaiuntuk menyelesaikan masalah yang akan datang. Tayubi (2005: 5) mengemukakan bahwa dalam memahami suatu 
Vol 2 No 2 Desember 2021

Jurnal AlphaEuclidEdu

Received: 21/12/2020; Resived: 24/08/2021; Accepted: 31/12/2021

konsep oleh siswa (konsepsi) bisa saja mengalami kesalahan sehingga konsepsi siswa berbeda dengan konsep yang telah disepakati olehpara ahli atau dengan kata lain siswa dapat dikatakan mengalami miskonsepsi.

Miskonsepsi didefinisikan oleh Suparno(2013: 8) sebagai konsepsi oleh siswa yang tidak selaras dengan konsep yang disepakati ahli-ahli. Miskonsepsi tersebut dapat meneyebabkan siswa sering mengalami kesulitan saat proses pembelajaran. Beberapahal ini dapat menyebabkan siswa mengalami miskonsepsi yakni pengetahuan awal yang dimiliki oleh siswa, pengajar, buku bacaan, dan lingkungannya. Pada tabel berikut ini disajikan penjelasan dari masing-masing penyebab miskonsepsi.

Tabel 1. Penyebab Miskonsepsi Siswa

\begin{tabular}{|c|c|c|}
\hline & Sebab Utama & Sebab Khusus \\
\hline \multirow[t]{8}{*}{1.} & \multirow[t]{8}{*}{ Siswa } & Prakonsepsi \\
\hline & & Pemikiran asosiatif \\
\hline & & Pemikiran humanistik \\
\hline & & Reasoning yang tidak lengkap \\
\hline & & Intuisi yang salah \\
\hline & & Tahap perkembangan kognitif siswa \\
\hline & & Kemampuan atau bakat siswa \\
\hline & & Minat belajar siswa \\
\hline \multirow[t]{4}{*}{2.} & \multirow[t]{4}{*}{ Guru atau Pengajar } & Bukan lulusan dari bidang ilmu matematika \\
\hline & & $\begin{array}{l}\text { Tidak membiarkan siswa mengungkapkan gagasan } \\
\text { atau idenya }\end{array}$ \\
\hline & & Tidak kompeten, tidak menguasai bahan \\
\hline & & Hubungan antara guru dan siswa tidak baik \\
\hline & \multirow[t]{6}{*}{ Buku Teks } & Penjelasan keliru \\
\hline & & Salah tulis, terutama dalam penulisan rumus \\
\hline & & Tingkat penulisan buku terlalu tinggi bagi siswa \\
\hline & & Siswa tidak tahu membaca buku teks \\
\hline & & $\begin{array}{l}\text { Buku fiksi sains kadang-kadang konsepnya } \\
\text { menyimpang demi menarik pembaca }\end{array}$ \\
\hline & & Kartun sering memuat miskonsepsi \\
\hline & \multirow[t]{7}{*}{ Konteks } & Pengalaman diri siswa \\
\hline & & Bahasa sehari-hari yang berbeda \\
\hline & & Teman diskusi yang salah \\
\hline & & Keyakinan dan agama \\
\hline & & Penjelasan orang tua/orang lain yang keliru \\
\hline & & Konteks hidup siswa (TV, radio,film yang keliru) \\
\hline & & Perasaan senang/tidak senang; bebas/tertekan \\
\hline & \multirow[t]{9}{*}{ Cara Mengajar } & Hanya berisi ceramah dan menulis \\
\hline & & Langsung ke dalam bentuk matematika \\
\hline & & Tidak mengungkapkan miskonsepsi siswa \\
\hline & & Tidak mengoreksi PR yang salah \\
\hline & & Model analogi \\
\hline & & Model praktikum \\
\hline & & Model diskusi \\
\hline & & Model demonstrasi yang sempit \\
\hline & & Non-multiple intelligences \\
\hline
\end{tabular}

Tabel 1 menunjukkan sebab utama dan sebab khusus miskonsepsi siswa. Berdasarkan tabel 1 di atas, penyebab miskonsepsi yang diungkap dalam penelitianini hanya salah satunya saja yaitu penyebab miskonsepsi yang berasal dari siswa terkait prakonsepsi, pemikiran asosiatif, pemikiran humanistik, reasoning yang tidak lengkap, dan intuisi yang 
Vol 2 No 2 Desember 2021

Jurnal AlphaEuclidEdu

Received: 21/12/2020; Resived: 24/08/2021; Accepted: 31/12/2021

salah.

Menurut Leading English Education and Resource Network (LEARN) (dalam Ramadhani, 2014: 17) dan Ashlock (dalam Purwanti, 2019: 9), miskonsepsi yang berasal dari siswa dipisahkan menjadi berbagai bentuk seperti pada tabel berikut.

Tabel 2. Bentuk Miskonsepsi

\begin{tabular}{|c|c|c|}
\hline No. & Bentuk Miskonsepsi & Keterangan \\
\hline 1 & miskonsepsi pengertian huruf & $\begin{array}{l}\text { berupa mengabaikan keberadaan huruf, } \\
\text { tidak dapat membedakan antara huruf yang } \\
\text { digunakan sebagai satuan dan sebagai } \\
\text { variabel, berpikir bahwa huruf sebagai suatu } \\
\text { objek, mempercayai ada aturan yang } \\
\text { digunakan untuk menggunakan angka dari } \\
\text { suatu huruf, berfikir bahwa suatu huruf } \\
\text { memiliki nilai tertentu, berpikir bahwa huruf } \\
\text { yang berbeda mewakili angka yang berbeda, } \\
\text { dan berpikir bahwa suatu huruf merupakan } \\
\text { perwakilan dari suatu bilangan asli }\end{array}$ \\
\hline & miskonsepsi notasi & $\begin{array}{l}\text { berupa kesalahan penggabungan huruf dan } \\
\text { angka disebabkan siswa berfikir simbol } \\
\text { operasi bukan merupakan bagian dari } \\
\text { jawaban dan juga dapat berupa mengabaikan } \\
\text { penggunaan tanda kurung ketika dibutuhkan }\end{array}$ \\
\hline 3 & miskonsepsi penggeneralisasian & $\begin{array}{l}\text { berupa tidak memahami pernyataan penting } \\
\text { dari sebuah metode, ketidakmampuan } \\
\text { menggeneralisasi karena kurang memahami } \\
\text { operasi aritmatika, dan tidak mampu } \\
\text { menggeneralisasi karena siswa tidak mampu } \\
\text { untuk menentukan metode yang } \\
\text { digunakannya }\end{array}$ \\
\hline 4 & miskonsepsi pengaplikasian aturan & $\begin{array}{l}\text { berupa mengabaikan tanda ketika } \\
\text { memanipulasi }\end{array}$ \\
\hline 5 & miskonsepsi perhitungan & $\begin{array}{l}\text { berupa kesalahan dalam perhitungan yang } \\
\text { didasarkan atas pembentukan pola yang } \\
\text { salah dalam perhitungan }\end{array}$ \\
\hline 6 & miskonsepsi penspesialisasian & $\begin{array}{l}\text { berupa menggunakan konsep yang sama } \\
\text { pada permasalahan yang berbeda }\end{array}$ \\
\hline
\end{tabular}

Tabel 2 menjelaskan ada enam bentuk miskonsepsi yang berkemungkinan terjadi pada siswa. Matematika memuat berbagai materi, salah satunya yaitu materi pertidaksamaan dan persamaan linear satu variabel yang memuat nilai mutlak. Adapun kemampuan dasar yang harus dicapai pada materi ini yaitu menjelaskan pertidaksamaan dan persamaan nilai mutlak linear satu variabel dan juga persamaan danpertidaksamaan linear aljabar yang lain, serta menemukan solusi dari persoalan terkait pertidaksamaan dan persamaan nilai mutlak linear satu variabel (Sinaga, 2017: 18).

Menurut informasi dari salah satu guru kelas X SMA Muhammadiyah 1 Pontianak, masih banyak siswa kelas $\mathrm{X}$ yang keliru dalammenyelesaikan soal matematika khususnya di materi pertidaksamaan dan persamaan linear satu variabel yang memuat nilai mutlak. Untuk memperkuat informasi tersebut, peneliti memberikan soal tes terkait materi tersebut kepada 10 siswa kelas X SMA Muhammadiyah 1 Pontianak. Jawaban 10 siswa itu menunjukkan masih banyak siswa yang keliru dalam menemukan solusi soal itu seperti jawaban siswa A terhadap soal yang diberikan oleh peneliti berikut.

6. Tinggi siswa di kelas $\mathrm{X}$ dikatakan sedang apabila tingginya mencapai $160 \mathrm{~cm}$, akan tetapi tinggi siswa ditoleransi boleh beda paling besar $5 \mathrm{~cm}$ dari tinggi yang dikatakan sedang. Tentukan model matematika dari permasalahan tersebut. 
Vol 2 No 2 Desember 2021

Jurnal AlphaEuclidEdu

Received: 21/12/2020; Resived: 24/08/2021; Accepted: 31/12/2021

\section{Gambar 1. Soal Tes Nomor 6}

Gambar 1 di atas menunjukkan soalnomor 6 yang diberikan oleh peneliti ke peserta didik. Di bawah ini jawaban darisiswa A.

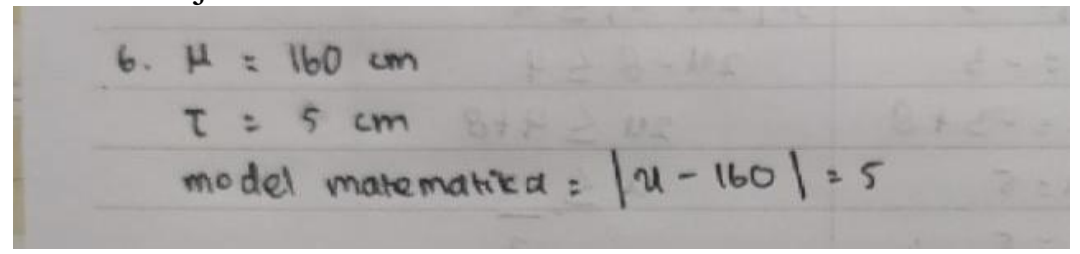

Gambar 2. Jawaban Tertulis Siswa A Terhadap Soal Nomor 6

Gambar 2 menunjukkan bahwa siswa salah dalam menentukan model matematika yang sesuai dengan permasalahan. Tanda penghubung yang seharusnya dipakai adalah tanda penghubung kurang dari sama dengan $(\leq)$. berikut.

Kesalahan lain dilakukan dengan siswa B terhadap soal yang diberikan oleh peneliti

\section{Tentukan nilai $x$ yang memenuhi pertidaksamaan nilai mutlak $|2 x-8| \leq 4$. Gambar 3. Soal Tes Nomor 3}

Gambar 3 di atas menunjukkan soal nomor 3 yang diberikan oleh peneliti ke peserta didik. Di bawah ini jawaban yang diberikan oleh siswa B.

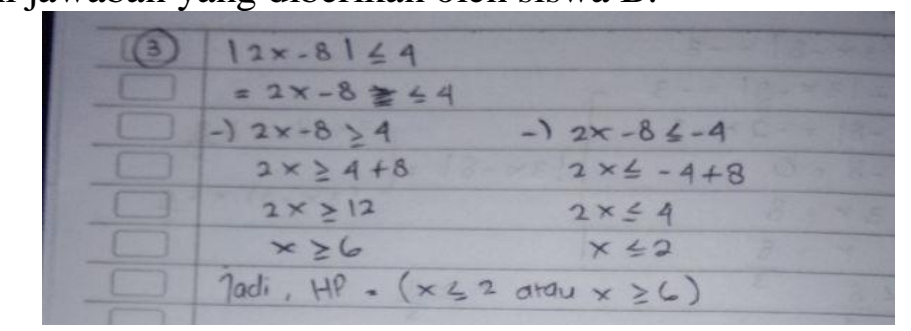

Gambar 4. Jawaban Tertulis Siswa B Terhadap Soal Nomor 3

Gambar 4 memperlihatkan siswa salah keliru mengaplikasikan aturan untuk menyelesaikan permasalahan tersebut. Aturanyang seharusnya digunakan yaitu bagi setiap $a, x$ bilangan real, jika $|x| \leq a$ maka $-a \leq x \leq a$. Dari jawaban siswa A dan siswa B dapat dilihat bahwa masih terdapat kekeliruan. Salah satu kesalahan yang dibuat yakni salah dalam menentukan model matematika. Fakta tersebut selaras dengan sebuah penelitian relevan yang dilaksanakan oleh Ibrahim (2020) dimana menunjukkan kekeliruan siswa berikut.

Dari fakta tersebut, menunjukkan bahwa ternyata masih ada kompetensi dasar yang belum tercapai yaitu menemukan solusi terkait persoalan pertidaksamaan dan persamaan nilai mutlak linear satu variabel. Apabila kekeliruan seperti pada fakta di atas itu terus menerus terjadi maka siswa dapat diduga mengalami miskonsepsi. Miskonsepsi yang terjadi dapat dideteksi melalui two-tier diagnostic test yang merupakan tes diagnostik dengan dua tingkatan. 
Vol 2 No 2 Desember 2021

Jurnal AlphaEuclidEdu

Received: 21/12/2020; Resived: 24/08/2021; Accepted: 31/12/2021

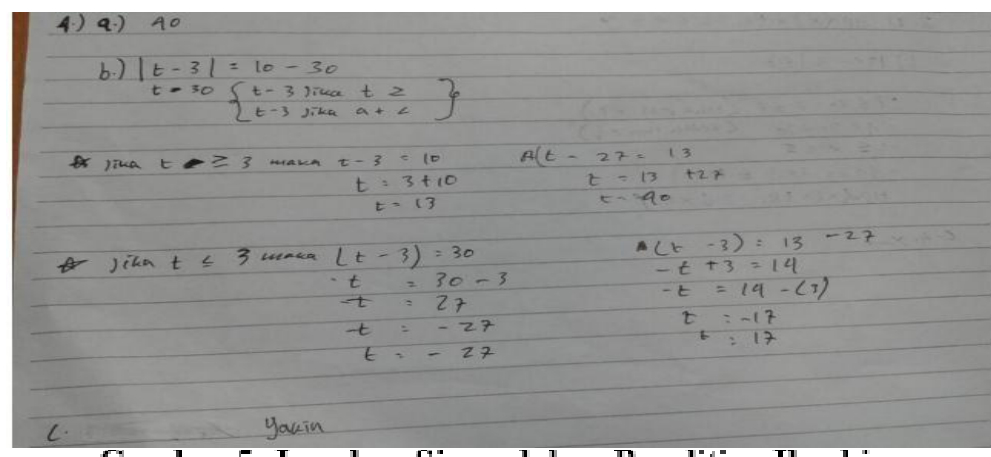

Gambar 5. Jawaban Siswa dalam Penelitian Ibrahim

Menurut penjelasan di atas, peneliti tertarik untuk menggali lebih dalam mengenai miskonsepsi peserta didik dalam menyelesaikan soal pertidaksamaan linear satu variabel yang memuat nilai mutlak. Dengan demikian, dalam penelitian ini dideskripsikan: (1) bentuk-bentuk miskonsepsi yang terjadi pada peserta didik dalam memecahkan persoalan pertidaksamaan linear satu variable yang memuat nilai mutlak di kelas X SMA Muhammadiyah 1 Pontianak, serta (2) mendeskripsikan factor penyebabmiskonsepsi peserta didik.

\section{Metode Penelitian}

Penelitian ini menggunakan metode deskriptif. Bentuk penelitiannya studi kasus. Subjek penelitian ini ialah siswa kelas X IPA 3 SMA Muhammadiyah 1 Pontianak sebanyak 25 siswa. Teknik yang digunakna untuk mengumpulkan data dalam penelitian ini ialah teknik tes beserta non tes. Sementara itu, alat yang digunakan sebagai pengumpul data di penelitian ini two-tier diagnostic test. Jumlah soal yang diberikan kepada siswa yaitu 8 butir yang sudah divalidasi oleh dosen dan guru matematika kelas X SMA Muhammadiyah 1 Pontianak. Jawaban siswa terhadap soal tersebut dapat diklasifikasikan ke dalam 3 kategori dengan ketentuan berdasarkan kombinasi dari jawaban two-tier diagnostic test seperti pada tabel berikut.

Tabel 3. Kombinasi Jawaban Two-Tier Diagnostic Test

\begin{tabular}{lc}
\hline \multicolumn{1}{c}{ Pola jawaban Siswa } & Kategori tingkat Pemahaman \\
\hline Jawaban inti tes benar-alasan benar & Memahami (M) \\
\hline Jawaban inti tes benar-alasan salah & Miskonsepsi (Mi) \\
\hline Jawaban inti tes salah-alasan benar & Tidak Memahami (TP) \\
\hline
\end{tabular}

Tabel 3 menunjukkan apabila kombinasi jawaban siswa berpola benar-benar maka siswa dapat diklasifikasikan ke dalamkategori memahami atau paham konsep (M), apabila kombinasi jawaban siswa berpola benar-salah dan salah benar maka siswa diklasifikasikan ke dalam kategori miskonsepsi (Mi), dan apabila kombinasi jawaban siswa berpola salahsalah makasiswa diklasifikasikan ke dalam kategori tidakpaham konsep (TP).

Selain dengan tes diagnostik, peneliti juga menggunakan pedoman wawancara sebagai alat pengumpulan data. Peneliti menggunakan pedoman wawancara non terstruktur untuk menggali informasi dari siswa. Langkah-langkah penelitian ini ialah sebagai berikut.

\section{Tahap Persiapan}

Tahap ini melipuiti: (1) menjalankan pra-survey di SMA Muhammadiyah 1 Pontianak, (2) merangkai alat-alat penelitian, (3) menjalankan validasi alat-alat penelitian, (4) memperbaiki alat-alat penelitian sesuai dengan hasil validasi, (5) mengadakan uji coba alat-alat penelitian, (6) menelaah data hasil uji coba alat-alat penelitian, (7) memperbaiki alat-alat penelitian sesuai sesuai dengan hasil uji coba, dan (8) menetapkan waktu penyelenggaraan penelitian. 
Vol 2 No 2 Desember 2021

Jurnal AlphaEuclidEdu

Received: 21/12/2020; Resived: 24/08/2021; Accepted: 31/12/2021

Tahap Pelaksanaan

Tahap ini melpiuti: (1) memberikan tes diagnostik kepada subjek penelitian; (2) menyortir siswa yang memahami (M), miskonsepsi (Mi), serta yang tidak memahami (TP); seta (3) melakukan wawancara kepada siswa yang terdeteksi miskonsepsi untuk mngetahui bentuk beserta penyebabnya.

\section{Tahap Akhir}

Tahap ini melpiuti: (1) menganalisis hasil jawaban soal tes beserta wawancara, (2) hasil penelitian dideskripsiakn, serta (3) menarik simpulan.

\section{Hasil dan Pembahsan}

\section{Hasil Penelitian}

Soal two-tier diagnostic test yang berjumlah 8 butir soal diberikan kepada 25 peserta didik dengan tujuan untuk mengetahui banyak siswa yang mengalami miskonsepsi di setiap butir soalnya. Berdasarkan jawaban siswa terhadap two-tier diagnostic test diperoleh hasil seperti pada tabel ini.

\begin{tabular}{ccccc}
\multicolumn{5}{c}{$\begin{array}{c}\text { Tabel 4. Rekapitulasi Jumlah Siswa Berdasarkan Two-Tier } \\
\text { Diagnostic Test pada Tiap Butir Soal }\end{array}$} \\
\hline $\begin{array}{c}\text { Butir } \\
\text { Soal }\end{array}$ & $\begin{array}{c}\text { Kategori Siswa } \\
\text { Konsep }\end{array}$ & Miskonsepsi & $\begin{array}{c}\text { Paham } \\
\text { Konsep }\end{array}$ & $\begin{array}{c}\text { Tidak } \\
\text { Menjawab }\end{array}$ \\
\cline { 2 - 5 } & 0 & 0 & 24 & 1 \\
\hline 1 & 1 & 1 & 22 & 1 \\
\hline 2 & 1 & 7 & 15 & 2 \\
\hline 3 & 1 & 2 & 21 & 1 \\
\hline 4 & 0 & 2 & 22 & 1 \\
\hline 5 & 8 & 2 & 14 & 1 \\
\hline 6 & 1 & 3 & 20 & 1 \\
\hline 7 & 15 & 0 & 9 & \\
\hline 8 & & & & 1 \\
\hline
\end{tabular}

Tabel 4 memperlihatkan banyak siswa pada masing-masing kategori pemahaman konsep. Berikut ini disajikan tabel rekapitulasi siswa yang miskonsepsi pada butir soal nomor 2, 3, 4, 5, 6, dan 7 .

\begin{tabular}{l}
\multicolumn{6}{l}{ Tabel 5. Rekapitulasi Siswa yang Mengalami Miskonsepsi pada Tiap Butir Soal } \\
\begin{tabular}{ccccc}
\hline Butir Soal & Jumlah & Kode Siswa & $\%$ \\
\hline 2 & 1 & FAG & $4 \%$ \\
\hline 3 & 7 & AFY, BA, FV, MZ, NHB, PA, WA & $28 \%$ \\
\hline 4 & 2 & FAG, RAS & $8 \%$ \\
\hline 5 & 2 & FAG, WA & $8 \%$ \\
\hline 6 & 2 & FT, NB & $8 \%$ \\
\hline 7 & 3 & AAP, DE, MFAV & $12 \%$ \\
\hline Jumlah & 17 & & \\
\hline
\end{tabular}
\end{tabular}

Menurut tabel 5 peserta didik paling banyak miskonsepsi di butir soal nomor 3 yakni 7 siswa atau sebanyak 28\%. Berdasarkan jawaban peserta didik terhadap soal two-tier diagnostic test serta hasil wawancara antara peneliti dengan peserta didik yang mengalami miskonsepsi diperoleh beberapa bentuk miskonsepsi dan penyebab miskonsepsi yang disajikan di tabelberikut. 
Vol 2 No 2 Desember 2021

Jurnal AlphaEuclidEdu

Received: 21/12/2020; Resived: 24/08/2021; Accepted: 31/12/2021

Tabel 6. Rekapitulasi Bentuk dan Penyebab Miskonsepsi Siswa

\begin{tabular}{lcccc}
\hline \multicolumn{1}{c}{ Bentuk Miskonsepsi } & Kode Siswa & Jumlah & $\%$ & $\begin{array}{c}\text { Penyebab } \\
\text { Miskonsepsi }\end{array}$ \\
\hline $\begin{array}{l}\text { Miskonsepsi Pengertian } \\
\text { Huruf }\end{array}$ & - & 0 & $0 \%$ & - \\
\hline Miskonsepsi Notasi & AAP & 1 & $4 \%$ & $\begin{array}{c}\text { Intuisi yang } \\
\text { Salah }\end{array}$ \\
\hline $\begin{array}{l}\text { Miskonsepsi } \\
\text { Penggeneralisasian }\end{array}$ & DE, FAG, MFAV & 3 & $12 \%$ & $\begin{array}{c}\text { Reasoning } \\
\text { yang Tidak } \\
\text { Lengkap dan } \\
\text { Intuisi yang } \\
\text { Salah }\end{array}$ \\
\hline $\begin{array}{l}\text { Miskonsepsi } \\
\text { Pengaplikasian Aturan }\end{array}$ & AFY, BA, FV, MZ, & 6 & $24 \%$ & $\begin{array}{c}\text { Reasoning } \\
\text { yang Tidak } \\
\text { Lengkap }\end{array}$ \\
\hline Miskonsepsi Perhitungan & FAG, WA & 2 & $8 \%$ & $\begin{array}{c}\text { Reasoning } \\
\text { yang Tidak } \\
\text { Lengkap }\end{array}$ \\
\hline $\begin{array}{l}\text { Miskonsepsi } \\
\text { Penspesialisasian }\end{array}$ & FT, NB, RAS & 3 & $12 \%$ & $\begin{array}{c}\text { Reasoning } \\
\text { yang Tidak } \\
\text { Lengkap }\end{array}$ \\
\hline
\end{tabular}

Tabel 6 menunjukkan bahwa peserta didik paling banyak mengalami miskonsepsi pengaplikasian aturan. Terdapat 6 siswa atau sebanyak 24\% siswa mengalami miskonsepsi pengaplikasian aturan dan kebanyakan miskonsepsi siswa disebabkan oleh rasoning yang tidak lengkap.

\section{Pembahasan}

Menurut data di tabel 6, diperolehinformasi bahwa ada lima bentuk miskonsepsiyang terjadi pada peserta didik kelas X IPA 3 SMA Muhammadiyah 1 Pontianak yakni miskonsepsi notasi, penggeneralisasian, pengaplikasian aturan, perhitungan dan penspesialisasian dengan penyebab intuisi yang salah dan reasoning yang tidak lengkap. Intuisi yang salah timbul secara spontan pada saat siswa sedang menyelesaikan soal. Hal ini selaras dengan pendapat Suparno (2013: 29) yang menyatakan bahwa miskonsepsi dapat disebabkan oleh pemikiran intuisi siswa yang sering membuat siswa tidak kritis terhadap pemikirannya tersebut. Intuisi yang dialami siswa muncul secara spontan dalam bentuk gagasan yang belum pernah dianalisis sebelumnya. Sedangkan reasoning yang tidak lengkap dapat dikarenakan siswa belum sepenuhnya memahami materi yang dijelaskan. Pernyataan itu sejalan dengan Comins (dalam Suparno, 2013: 38) menjelaskan bahwa miskonsepsi dapat disebabkan oleh reasoning yang salah atau tidak lengkap yang terjadi karena penalaran atau logika peserta didik salah dalam membuat keseimpulan atau generalisasi. Selain itu, pengamatan siswa yang tidak lengkap dan tidak akurat juga dapat menyebabkan kesimpulan yang salah dan mengakibatkan miskonsepsi.

Tabel 5 memperlihatkan bahwa AAP terdeteksi miskonsepsi pada soal butir 7 serta bentuk miskonsepsinya ialah notasi yang tertera di tabel 6 . Tabel 6 juga memperlihatkan bahwa penyebab miskonsepsinya ialah intuisi yang salah. AAP menyelesaikan soal nomor 7 dengan menggabungkan angka dan huruf yang beradadi dalam kurung mutlak sehingga $\mid x-$ $80 \mid<20$ menjadi $|-80 x|<20$ dan AAP memilih alasan pada opsi C yaitu jawaban diperoleh dengan menggabungkan suku-suku yang tidak sejenis. Seharusnya $|x-80|<20$ menjadi $-20<x-80<20, x-80$ tidak bisa digabung menjadi $-80 x$. Hasil jawaban AAP menunjukkan bahwa AAP menyamakan angka dan huruf yang posisinya sebagai nilai mutlak tersebut. Kemudian FAG merubah $|2 x+4|-|3 x+6| \geq 0$ menjadi $2 x+4 \geq 0$ dan $3 x$ $+6 \geq 0$, lalu menentukan nilai $x$ dari masing-masing pertidaksamaan yaitu untuk $2 x+4 \geq 0$ kedua ruasnya dikurang 4 dapatlah $2 x \geq-4$ kemudian kedua ruasnya dikali dengan 1 dapatlah $x \geq$ variabel di dalam kurung mutlak tersebut serta AAP mengerjakan soal tersebut 
Vol 2 No 2 Desember 2021

Jurnal AlphaEuclidEdu

Received: 21/12/2020; Resived: 24/08/2021; Accepted: 31/12/2021

sesuai dengan -2 dan untuk $3 x+6 \geq 0$ kedua ruas gagasannya sendiri yang muncul secara spontan ketika mneyelesaikan soal.

Terlihat dari tabel 6 ada sebanyak 3 siswa yaitu DE, FAG, dan MFAV yang mengalami miskonsepsi penggeneralisasian. DE menyelesaikan soal nomor 7 tidak menggunakan konsep nilai mutlak tetapi dengan menggunakan rumus jarak dimana 20 sebagai jarak dan 80 sebagai kecepatan, kemudian DE menghitung jarak dibagi dengan kecepatan sehingga diperoleh hasil $20 / 80=1 / 4$. DE memperoleh gagasan tersebut dari pikiran atau penalarannya sendiri yang kurang lengkap. Reasoning atau penalaran DE yang kurang lengkap ini menyebabkan DE mengalami miskonsepsi. Dari jawaban DE, dapat terlihat bahwa DE kurang memahami konsep nilai mutlak.

Gagasan DE dalam menyelesaiakan soal nomor 7 mirip dengan cara yang MFAV lakukan yakni tidak menggunakan konsep nilai mutlak tetapi langsung dengan operasi pembagian yaitu $20 \mathrm{~km} / 80 \mathrm{~km}$ sehingga diperoleh 1/4. Cara tersebut muncul dalam benak MFAV secara spontan ketika MFAV menyelesaikan soal. Hal ini berarti cara tersebut diperoleh dari intuisi MFAV yang salah sehingga mengakibatkan MFAV tidak dapat mengambil kesimpulan atau menggeneralisasi dengan tepat metode apa yang dapat digunakan untuk menyelesaikan soal nomor 7. Jawaban MFAV menunjukkan MFAV belum memahami dengan tepat konsep nilai mutlak.

Lain halnya dengan FAG, FAG terdeteksi mengalami miskonsepsi penggeneralisasian di soal butir 5. FAG menyelesaikan soal butir 5 dengan menggunakan aturan yang tak sesuai yaitu $|2 x+4| \geq|3 x+6|$ menjadi $|2 x+4|-|3 x+6| \geq 0$ tanpa mengkuadratkan kedua dikurang dengan 6 diperoleh $3 x \geq-6$ kemudian kedua ruas dikali dengan diperoleh $x \geq-2$. Seharusnya pada $|2 x+4| \geq|3 x+6|$ kedua ruas dikuadratkan terlebih dahulu agar kurung mutlaknya tidak ada baru kemudian dilanjutkan dnegan operasi-operasi pertidaksamaan untuk memperoleh nilai $x$. Cara tersebut FAG peroleh dari intuisinya sendiri. Intuisi FAG yang masih salah ini mengakibatkan FAG tidak dapat mengambil kesimpulan atau menggeneralisasi dengan benar metode yang seharusnya diterapkan untuk menyelesaikan soal nomor 5 sehingga dapat diperoleh kesimpulan bahwa FAG kurang paham tentang konsep nilai mutlak.

Siswa dengan kode AFY, BA, FV, MZ, NHB, dan PA terdeteksi mengalami miskonsepsi pengaplikasian aturan pada soal nomor 3. AFY, BA, FV, MZ, NHB, dan PA menyelesaikan soal nomor 3 dengan cara yang benar, tetapi terdapat kesalahan yaitu $-20 x>$ 20 menjadi $x>-1$, seharusnya $-20 x>20$ menjadi $x<-1$. AFY, BA, FV, MZ, NHB, dan PA yakin bahwa pengerjaannya sudah benar. Hal ini disebabkan karena informasi yang diperoleh saat pembelajaran kurang detail dan berlanjut terjadi ketika siswa menyelesaikan soal dimana reasoning siswa atau penalarannya tidak lengkap sehingga menyebabkan miskonsepsi. Dari jawabannya, keenam siswa tersbeut masih kurang memamhami sifat pertidaksamaan linear dimana ketika kedua ruas dikali atau dibagi dengan bilangan negatif maka tanda pertidaksamaan akan berubah.

Dalam tabel 6 juga diperoleh informasi mengenai siswa yang mengalami miskonsepsi perhitungan sebanyak 2 siswa yaitu FAG dan WA. FAG terdeteksi mengalami miskonsepsi perhitungan pada soal butir 2 serta 4 . FAG menyelesaikan soal butir 2 serta 4 dengan cara yang benar, tetapi terdapat kesalahan menghitung seperti pada nomor 2 yaitu $x^{2}+8 x+16-$ $x^{2}+12 x-36<0$ menjadi $x^{2}+20 x-20<0$ dan pada nomor 4 yaitu $x^{2}+2 x+1-x^{2} \leq 0$ menjadi $x^{2}+2 x+1 \leq 0$ sehingga pada jawaban FAG masih terdapat variabel $x^{2}$, seharusnya variabel tersebut sudah tidak ada karena sudah dikurangkan dengan variabel yang sejenis. FAG yakin bahwa perhitungannya tersebut sudah benar sehingga dapat disimpulkan bahwa FAG kurang memahami operasi aljabar.

Sementara itu, WA terdeteksi mengalami miskonsepsi perhitungan di soal butir 3 
Vol 2 No 2 Desember 2021

Jurnal AlphaEuclidEdu

Received: 21/12/2020; Resived: 24/08/2021; Accepted: 31/12/2021

serta 5. WA menyelesaikan soal butir 3 serta 5 dengan cara yang benar, tetapi pada soal nomor 3 terdapat kesalahan menghitung yaitu $x-4-(x+6)=2 x-10$, seharusnya $x-4-$ $(x+6)=-10$. Kemudian pada soalnomor 5 terdapat kesalahan menghitung yaitu $2 x+4-$ $(3 x+6)=10-x$, seharusnya $2 x+4-(3 x+6)=-x-2$. Sedangkan WA yakin bahwa perhitungannya sudah benar. Hal ini disebabkan karena penalaran yang WA milikiketika mengerjakan soal tidak lengkapsehingga menimbulkan miskonsepsi. Darijawaban WA pada nomor 3 dan 5 menandakan bahwa WA kurang memahami operasi aljabar.Dari tabel 6 memberikan informasi bahwa sebanyak 3 siswa yaitu FT, NB, dan RAS mengalami miskonsepsipenspesialisasian. FT dan NB terdeteksimengalami miskonsepsi di soal butir 6. FT dan NB menyelesaikan soal butir 6 dengan menggunakan salah satu aturan atau sifatpertidaksamaan linear satu variabel seperti $x-20<80$ menjadi $x-20+20<80+$ 20 dan hasil akhirnya $x<100$, sedangkan soal yang diberikan adalah soal pertidaksamaan nilai mutlak. Jawaban seharusnya ialah $x-20<80$ menjadi $-80<x-20<80$ dan hasil akhirnya $-60<x<100$. FT dan NB menyamakan cara penyelesaian soal pertidaksamaan nilai mutlak dengan soal pertidaksamaan linear satu variabel sehingga dapat disimpulkan bahwa FT dan NB kurang memahami konsep nilai mutlak. Hal ini disebabkan oleh penalarannya ketika menyelesaiakn soal tersebut tidak lengkap.

Siswa dengan kode RAS terdeteksi miskonsepsi penspesialisasian di nomor 4. RAS menyelesaikannya dengan menggunakan salah satu sifat pertidaksamaan nilai mutlak "Jika $|x| \leq a$ maka $-a \leq x \leq a$ ". Jawaban RAS yakni $|x+1| \leq|x|$ dirubah menjadi $-x \leq x$ $+1 \leq x$. Padahal sifat tersebut tidak sesuai untuk digunakan dalam menyelesaikan soal nomor 4. Seharusnya $|x+1| \leq|x|$ kedua ruasnya dikuadratkan sehingga menjadi $|x+1|^{2} \leq$ $|x|^{2}$. RAS menyamakan cara penyelesaian soal pertidaksamaan nilai mutlak linear satu variabel yang memuat 1 kurung mutlak dengan soal pertidaksamaan nilai mutlak linear satu variabel yang memuat 2 kurung mutlak sehingga dapat disimpulkan bahwa RAS kurang memahami konsep nilai mutlak.

\section{Simpulan dan Saran Simpulan}

Menurut uraian di atas diperoleh kesimpulan bahwa terdapat lima bentuk miskonsepsi siswa dalam menyelesaikan soal pertidaksamaan linear satu variabel yang memuat nilai mutlak di kelas X SMA Muhammadiyah 1 Pontianak yaitu miskonsepsi notasi sebanyak 1 siswa, penggeneralisasian sebanyak 3 siswa, pengaplikasian aturan sebnayak 6 siswa, perhitungan sebanyak 2 siswa, serta penspesialisasian sebanyak 3 siswa. Selain itu, disimpulkan juga bahwa penyebab miskonsepsi yang dialami siswa ialah intuisi yang salah dan reasoning yang tidak lengkap, dimana pemikiran intuisi siswa yang muncul secara spontan saat menyelesaikan soal masih salah dan penalaran atau logika siswa yang masih salah dalam mengambil kesimpulan serta terlalu luas dalam menggeneralisasi. Intuisi yang salah dan reasoning yang tidak lengkap ini diduga terjadi karena siswa kurang memahami konsep nilai mutlak, kurang memahami sifat-sifat pertidaksamaan, dan kurang memahami operasi aljabar sehingga pemahaman siswa terhadap materi yang diajarkan tidak lengkap.

\section{Saran}

Menurut hasil penelitian, peneliti menyarankan: (1) alangkah baiknya untuk peneliti selanjutnya meneliti materi lainnya yang lebih kompleks seperti materi persamaan atau pertidaksamaan kuadrat agar penelitian mengenai identifikasi miskonsepsi dalam menyelesaikan soal nilai mutlak selanjutnya lebih berkembang; (2) bagi penelitiselanjutnya, sebaiknya meneliti miskonsepsi dengan menggunakan alat pengumpulan data yang lebih canggih lagi seperti tes diagnostik yang terdiri dari empat tingkatan (four-tier diagnostic test) karena alat tersebut dapat mendeteksi bentuk miskonsepsi dan penyebab miskonsepsi 
Vol 2 No 2 Desember 2021

Jurnal AlphaEuclidEdu

Received: 21/12/2020; Resived: 24/08/2021; Accepted: 31/12/2021

lebih akurat dari two-tier diagnostic test; dan (3) bagi pendidik, sebaiknya penyampaian mengenai konsep nilai mutlak lebih diperjelas lagi dan dicek kembali apakah siswa sudah memahami materi prasyarat.

\section{Referensi}

Depdiknas. 2006. Peraturan Menteri Pendidikan Nasional Republik Indonesia tentang Standar Isi untuk Satuan Pendidikan Dasar dan Menengah. Jakarta: Depdiknas.

Firdaus, H. 2017. "Tujuan pembelajaranMatematika di Sekolah Dasar". https://www.blogbarabai.com/2017/09/ tujuan-pembelajaran-matematikadi.html\#: :text=Tujuan\%20pembelajar $\quad$ an\%20matematika\%20di\%20sekolah\% 20dasar\%20secara\%20umum\%20adala $\quad$ h\%20agar,penataran\%20nalar\%20dala m\%20penerapan\%20matematika.\&text =Memecahkan\%20masalah\%2C\%20m elakukan\%20penalaran\%2C\%20dan\% 20mengomunikasikan\%20gagasan\%20 secara\%20matematika. Diakses pada 19 Agustus 2020 pukul 16.00 WIB. Ibrahim, Febrian, \& Ramadhona, R. 2020. Miskonsepsi Siswa dalam Menyelesaikan Soal PertidaksamaanNilai Mutlak Linear Satu Variabeldengan Menggunakan Three Tier Test. Student Online Journal. 1(1): 529-538.

Isyam, Y. A. N. 2019. Identifikasi Miskonsepsi Siswa dalam Menyelesaikan Soal TIMSS Konten Aljabar Ditinjau dari Tingkah Kecemasan Matematika. Kadikma. 10(1):74-84.

Purwanti, P. 2019. "Miskonsepsi Siswa pada Materi Operasi Hitung Bentuk Aljabar Di Kelas VII SMP Kemala Bhayangkari”. Skripsi. FKIP. Pendidikan Matematika. Universitas Tanjungpura. Pontianak.

Ramadhan, M., Sunardi, \& Kurniawati, D. 2017. Analisis Miskonsepsi Siswa dalam Menyelesaikan Soal Matematika Berstandar PISA dengan Menggunakan Certainty of Response Index (CRI). Kadikma. 8(1): 145-153.

Ramadhani, W. H. 2014. "Miskonsepsi Siswapada Materi Operasi Bentuk Aljabar Di Kelas VII SMP Haebat Islam Kubu Raya". Skripsi. FKIP. Pendidikan Matematika. Universitas Tanjungpura. Pontianak.

Rohmah, Z., \& Handhika, J. 2018. Two-Tier Test Diagnostic sebagai Identifikasi Miskonsepsi Tahap Awal Materi Kinematika Gerak Lurus Siswa Kelas X MAN 1 Kota Madiun. Prosiding Seminar Nasional Quantum. ISSN:2477-1511.

Sinaga, Bornok. 2017. Buku Guru Matematika SMA/SMK/MAK Kelas X. Buku Sekolah Elektronik (BSE). Jakarta: Pusat Kurikulum dan Perbukuan, Balitbang, Kemendikbud.

Suparno, P. 2013. Miskonsepsi \& Perubahan Konsep dalam Pendidikan Fisika. Jakarta: Grasindo.

Tayubi, Y. R. 2005. Identifikasi Miskonsepsi pada Konsep-Konsep Fisika Menggunakan Certainty of Response Index (CRI). Mimbar Pendidikan. 24(3): 4-9. 